\title{
Investigating students' reflection toward self-assessment on creative writing achievement in ESP course
}

\author{
Sumarni ${ }^{1}$, Muhammad Miftah Fauzan ${ }^{2}$, Samah Ali Mohsen Mofreh ${ }^{3}$, \\ Andi Anto Patak ${ }^{*}$ \\ ${ }^{1}$ Universitas 17 Agustus 1945, Samarinda, Indonesia \\ e-mail: ninimarni@gmail.com \\ ${ }^{2,4}$ Universitas Negeri Makassar, Makassar, 90221, Indonesia \\ email: ${ }^{2}$ fauzanjourney@icloud.com, ${ }^{* 4}$ andiantopatak@unm.ac.id \\ ${ }^{3}$ School of Educational Studies, Universiti Sains Malaysia, Pulau Pinang, 11800, \\ Malaysia \\ email: samahmofreh@usm.my
}

\begin{abstract}
It not only seeks any ways of assessing student progress towards meeting outcome goals about professionalism, provides feedback and encourage students to take responsibility for setting and achieving high standards of performance, but also involve a direction to the whole teaching how great it supposed to be. This study investigates 45 students of 5 meetings English course at Computer and Informational Technology Faculty, Mulawarman University by using self-assessment followed by an in-depth interview. The instruments used for the survey is a self-made questionnaire based on literature review. In the beginning, a questionnaire was delivered to students to get primary students' reflection of various writing tasks-specifically or general English terms in many genres - before seeking information was widely involved in an interview of 5 students. The results of this study revealed that $96 \%$ of students agreed that they had engaged in useful reflection using self-assessment to the course and $91 \%$ agreed that the experience was worthwhile. A further $76 \%$ of students agreed that they could see opportunities if many approaches appear in some ways as results of a various writing exercise. For specifically or General English terms of various writing tasks, mostly they favor a creative essay more than a specific essay. This study is believed that it might be as strong recommendation to attend the satisfactory grounding and integrating English on ESP. It also can support for future research what ESP designing supposed to be.
\end{abstract}

\section{Keywords:}

English for Specific Purposes; self-assessment; written assignments; reflections

\section{INTRODUCTION}

It is widely recognized that feedback is an essential part of the learning cycle and it is believed involving the need for either student or teacher in teaching and learning process. Provides feedback and encourage students to take responsibility for setting and achieving high standards of performance is not only seeks any ways of assessing student progress towards meeting outcome 
goals about professionalism, but also involve a direction to the whole teaching how great it supposed to be.

Teachers are required to carefully look at the material in which the student becomes interested in it. One of them is creative writing. For some researchers, creative writing is an activity that can motivate students to develop their language skills because this process provides a full space for someone to think in their way writing that will be produced by them. Burkšaitiene (2014) suggest that to nurture creativeness in the different course in English, students' selfperception, the awareness level of creativity and creative writing, as well as their expectations, are important. The strength of students' works creatively is the awareness to lay their imagination flowing during the time than create works. It works by the right establishing for many parts in the learning process and can be supported if teacher using the right courses designing.

English Language Teaching (ELT) has experienced many changes and paradigm shifts during its brief lifetime (Graddol, 2007; Legutke \& Thomas, 1991; Richards \& Rodgers, 1986). The propositional-process paradigm shift was one of a number which led to the student being placed at the center of learning, managing the learning process. In another tectonic movement, work in the early part of the 20th century identified group work and collaboration as more effective than the individual competition regarding the effectiveness of learning (Vygotsky, 1978). At the root of many changes, it has placed problemsolving that students do not learn what teachers teach (Allwright, 1984) and can apply the things they have learned in school to real-life situations.

By goal oriented, good courses designing, teaching collaboration mentioned above and concern on what specific skill of English four skills and language knowledge is studied, ESP course is conducted to any universities. ESP program in such way has long been present in every university in Samarinda in different regulation each semester. This program remains a subject that must be taken by the students. The presence of this program is not the same in every university. For major universities such as Mulawarman University, on average holds ESP for only one semester. Other universities around it also follow it. Despite that, many colleges, Mulawarman University alike, still has a potential poor English performance. To specify English communicatively, most colleges had an inadequate satisfactory value of that. Facing this problem, the investigation should be presented. To ensure the effectiveness of ESP, many factors need to be taken into account before implementing ESP courses.

ESP is an English language course in non-English faculties. ESP lectures usually hold one to two semesters from the average 7-8 semesters of college attainment duration. The class meetings take two hours in a week, for twelve to fifteen meetings in one semester. As international communication, it becomes more accessible and faster whereas. English for specific purposes (ESP) has become an essential branch in English language teaching. English becomes professionals increasingly demand ESP programs to match the development in their field. The demand for this program is to meet the needs of English proficiency as a part of a professional job. The achievement of this 
proficiency is the responsibility of every university as well as a challenge to make it happen.

ESP is presented to accommodate students' communication skills more communicative. ESP is presented to answer some questions about why there are still many students are weak towards general or basic language comprehension even in simple communication. According to facilitate the courses communicatively, courses design must be established. The establishment should not be likely as English General Purposes. The design of this courses is divided separately and be involved carefully inside courses between the knowledge and the skill. It becomes completing one another based on the significant subject of field study. Four skills of language and the grammar might be placed regarding the need for colleges, and the workplace is supposed to be.

The development of language skills in the ESP class requires the accuracy of teachers in the design of learning materials and the instructions that follow. Courses designing must take attention to what approaches covering this courses. The fact that teacher oriented is not suitable for ESP, many practitioners change it into learner-oriented and directly in this process going through the goal-oriented. The implementation of learning was changed from teacher oriented to student-oriented. Since ESP is learner-centered and goaloriented, a more substantial burden and greater responsibility are thus imposed on the ESP teacher, as compared with those of the general English teacher. Wu (2014) showed that the motives for the emergence of all ESP programs were the difficulties of the electronic age, a revolution in linguistics, and the learner's focus. Learner needs for revolutionary linguistics were the fundamental motive for the emergence of ESP programs. The considerable development in methodical, practical, and economic accomplishments enlarged the claim for learning of ESP courses. However, innovative linguists focused on how languages were used in real situations that the English must change when the particular context was given.

ESP practitioner is expected to possess specialized knowledge and language-teaching skills at once. The ESP practitioner has as various as five key roles to implement. The roles include teacher, course designer and materials provider, collaborator, researcher, and evaluator. ESP teacher may need to work with a team teaching with the subject specialist both in and out of the classroom. The ESP instructor is also encouraged to undertake classroom action research to understand the learning effects and to improve ESP instruction. Moreover, last but not least, the ESP teacher should evaluate courses regularly to identify students' problems and to make proper adjustments accordingly. By using self-assessment, it is stated to bridge in the beginning answering the following question:

a) What problem might colleges have in ESP?

b) What writing material colleges favor?

c) What is required of ESP colleges? 


\section{LiTERATURE REVIEW}

In the recent day, to establish the great material designing, practitioner assess it in any assessment (Patak, Naim, Said, \& Asik, 2013). It is done not only to involve any evaluating of a lesson plan and the result examination but it is also to bridge students-teacher views insight of the learning process. The research results also bring up the latest innovative developments. One of them is the use of self-assessment as a learning evaluation process. Self-assessment is now a trend because it has been widely used in learning and teaching. This assessment method is based on how learners evaluate their learning of linguistics. The strength of this assessment method is the formation of a thorough success of the learning experience of students because the discovery of learning weakness is from the process of finding itself. The prominence and importance of selfassessment is confirmed by a multitude of publications in this area. Success in learning often depends on students' interest and subsequent motivation to study. Wu (2014) mentioned that the course design addresses learner needs, such as English for civil servants, for a police officer, and for officials of the law. Regardless of learner needs, ESP programs should focus on various learning strategies, schema, motivations, and interests.

Jones (2004) cite that assessment for learning sustains practitioners to focus on the learner and learning in individual classroom terms. How one of the assessments for principal themes of learning strategy, quality feedback, can be used to help learners progress. Many teachers have expressed apprehension in current years that the introduction of burdensome assessment necessities diminishes from the effective classroom and inhibits them meeting learners' needs. There is some evidence that self-assessment can be useful. Jabbarifar (2009) state that a capable, goal-oriented, teaching-learning sequence contains clearly understood objectives, productive classroom activities, and a sufficient amount of feedback to make students aware of the strengths and weaknesses of their performances. Feedback and evaluation are inseparably related to both instructional objectives and classroom learning activities and are indispensable elements in the learning process.

Among studies related to the impact of assessment on EFL writing skills (Fahed al-Serhani, 2007; Ghoorchaei, Tavakoli \& Ansari, 2010; Yurdabakan \& Erdogan, 2009), investigated the impact of assessment on Iranian EFL learners' writing skills. The results indicated that assessment had a statistically significant effect on writing performance of EFL Iranian learners. Furthermore, students had a positive attitude towards assessment. The five key characteristics of the portfolio are an alternative to the traditional testing, comprehensive ways to assess students' knowledge and skills, the authenticity of assessment, students' active participation in the evaluation process, simultaneous development of students' reflective thinking (Hamp \& Condon, 2000). For some teachers, the portfolio is a part of an assessment program, and it can either include a record of students' achievements or document their best work.

The reflections or commentaries on the entries which are typically presented in portfolios are central to portfolios. Through reflections students 
can develop metacognitive awareness of texts and situations, can advance their strategies on various tasks as well as may judge their work and compare performance in unique projects. There are three reasons for engaging learners in selfassessment and taking account of the results (Little, 2005). Firstly, a learnercenteredness; secondly, self-assessment, and thirdly, a tool for lifelong language learning. The most important feature of the ELP is that it supports reflective learning in which self-assessment and goal setting take the part of a dominant role.

The students' experiences using the portfolio framework were investigated by investigating the reflections of the learners' written. Only one-fifth of the seventy-three participants adored project work. One quarter had mixed feelings, and $57 \%$ observed it adversely. Furthermore, the high drop-out rate from the course existed since some students bring into being the course too challenging or thought English classes should be restricted to the study of language and resented being asked to achieve non-linguistic assignments. However, the portfolio assessment challenges to language learners include lower comparability and reliability and difficulty ensuring standardized testing conditions. They also pose a scoring problem because this criterion requires staff training and is more time- consuming than scoring a single normreferenced test (Gomer 2001). The definition of the portfolio can shift from product to process according to the context and design of its development (Nunes, 2004).

Among studies related to the impact of portfolio assessment on EFL writing skills (Fahed al-Serhani, 2007; Ghoorchaei, Tavakoli \& Ansari, 2010; Yurdabakan \& Erdogan, 2009), investigated the impact of portfolio assessment on Iranian EFL learners' writing skills. The results indicated that portfolio assessment had a statistically significant effect on writing performance of EFL Iranian learners. Furthermore, students had a positive attitude towards portfolio assessment.

According to Nunan (1988), there is a considerable extent of the mismatch between teachers and learners perceptions of the usefulness of diverse activities. Interestingly, a study by Spratt (1999) was conducted to compare learners' preferred activities with teachers' perceptions of what those preferences were, and only a roughly $50 \%$ of correlation was found. Similarly, another researcher (McDonough 2002), reported learners' dislikes such as listening to tapes and course book dialogues, and preferred grammar exercises, reading aloud, translation as being useful to learning. Granting there have been some studies on the self-assessment impact for improving writing skills and exploring their attitudes on portfolios, there necessities to ensure further experiential studies. Further studies require investigating the effect of portfolios on enhancing writing skills, particularly, on sub-skills of writing like organization, vocabulary, focus, conventions, and elaboration in ESP classes. As Galina, Ligija, and Lilija (2007) results showed that self-assessment was beneficial for learners' linguistic development

Summing up the references, it is important for ESP practitioners to clarify what are students' attitudes to various assignments, to analyze feedback constantly and to adjust teaching methods to learners' changing needs. 


\section{3 МЕTHOD}

This study investigated 45 students of 8 meetings English course at Computer and Informational Technology Faculty, Mulawarman University by using selfassessment followed by deep interview. The instruments used for the survey is a self-made questionnaire based on literature review. At the beginning, questionnaire were delivered to students in order to get primary students' reflection of various writing tasks-specifically or general English terms in many genre - before seeking information was widely involved in an interview of 5 students.

\section{Results}

The following are students' self-assessment on writing

Table1. Self-writing assessment

\begin{tabular}{lc}
\hline \hline \multicolumn{1}{c}{ Writing } & Yes \\
\hline \hline I can write summaries from articles in my discipline area & $36 \%$ \\
I know how to take notes in lectures & $56 \%$ \\
I can describe processes or events in writing & $36 \%$ \\
I can express my own opinions clearly on a range of topics & $57 \%$ \\
I can present arguments in a systematic way in an essay & $20 \%$ \\
I can write an extended report & $25 \%$ \\
I understand the concept of 'referencing' as it applies within Curtin & $15 \%$ \\
I am confident that I can avoid plagiarizing other texts when I write & $21 \%$ \\
I can write in a range of styles according to the audience and purpose & $10 \%$ \\
Self - assessment engage me as a useful reflection in writing & $96 \%$ \\
\hline \hline
\end{tabular}

Although students have poor confidence in writing, write an essay (20\%), an event sequence $(36 \%)$, extend report $(25 \%)$, write in specific purposes $(10 \%)$, but there are some positive statements on writing skills, - such as the ability to record lecture material from lecturers (56\%) and freedom of expression (57\%). This is the basis for further investigation by conducting intensive interviews (on students' reflection)

a) To question: "What problem might colleges have in ESP" which is probably assumed as a prior knowledge to write, following are students' reflections

Student 1: In my senior high school, we were less of getting writing task Student 2: I wrote but there was no adequate assessment from the teacher. I did not know my poor on writing

Student 3: At that time the teacher just always ordered us to answer the grammar and rarely assigned to write.

Student 4: I came from a village which is no good services of teacher attendance coming there.

b) What writing material colleges favor?

Student 1: I can write poetry because it is free on grammar 
Student 2: I am more comfortable making short stories about my life experience than explaining various professions in IT because I have not information about the IT profession

Student 3: Creative writing allows us to imagine using the desired words freely.

Student 4: Creative writing involves free thinking without being fixed one particular topic.

c) What is required of ESP colleges?

Student 1: I need more meeting for English

Student 2: if second attendance on next semester will be, I suggest to the fourth or fifth semester. Because that it must be preparation in TOEFL as a requirement going to proposal seminar.

Student 3: As a preparation getting a job, we need more learning in English Student 4: if English will be on next semester, it is better if there is a collaboration between language teacher and lecturer of a specific study.

Student 5: General English is an urgency placed well before going to learn the specific one.

Student 6: I agreed that the experience was worthwhile

\section{Discussion}

Based on students' reflection drawn above, it is stated that short courses such as in the most lecturing for each faculty of UNMUL Samarinda is not enough to facilitate students' need to learn EFL that is urgency. The integrated collaboration of two different lectures (English lecturer and major field study lecturer) is a part of students' need to what accurate of material they think better appeared in lecturing. Establishing in what semester ESP should be placed is still believed as a good recommendation for the institution to design it furthermore.

A variety of accurate information is obtained through the process of combination between various writing activities and self-assessment in this research. The role of self-assessment, in this case, is great for seeing each student's self-reflection. It can be concluded that the application of selfassessment as part of teaching English for specific purposes is urgent to do. In this study, the findings of previous survey and interview results show the same results with this study.

Previous research concludes that self-assessments are an excellent tool for evaluating ESP learning and learning in high school. In my research, the same stating appears that it is facilitated by the application of various writing assignments as reference learning achievements which is followed up with self-assessment, clearly showing the true student needs of whatever they want in the ESP class. The limited amount of field study is the main reason why need analysis is necessary to be learnt. Also, accurate lesson plan of ESP course is lead to learning outcomes that is satisfying not only for learners but also for the lecturers themselves.

Recommendations for immediate self-assessment are urgent to be done especially in the ESP Course. English teachers need to examine learners 'ongoing feedback and self-evaluation which can help them adjust their 
teaching to students' needs. Learner's individual written reflections and selfassessment serve best to analyze student's personal difficulties and dislikes, such as grammar, writing essays or listening to long passages. An individualized approach allows teachers to gain their learner's trust and to think about how to foster their linguistic development. As a conclusion, this study is believed that it might be as strong recommendation to attend the satisfactory grounding and integrating English on ESP. It also can support for future research what ESP designing supposed to be.

\section{Conclusion}

The results of this study revealed that $96 \%$ of students agreed that they had engaged in useful reflection using self-assessment to the course and $91 \%$ agreed that the experience was worthwhile. A further $76 \%$ of students agreed that they could see opportunities if many approaches appear in some ways as results of a various writing exercise. For specific or general English terms of various writing tasks, mostly they favor a creative essay more than a specific essay. By involving in-depth interview of 5 students' represent students', stated that (1) most students had not adequate opportunity doing writing in their previous school, so it is believed as a reason of their poor performance, (2) students in general likely were attracted writing in their way creatively such as personal essay more than explained the informational technology profession, (3) Students need to: a have and focus a satisfactory grounding in necessary English skill before they advance to ESP learning (4) the English language strategy should be emphasized separately even these opinions have a little difference of colleges one another, and (5) the need for second attendance for ESP is still as a majority required by colleges. Overall, this study is believed that it might be as strong recommendation to attend the satisfactory grounding and integrating English on ESP. It also can support for future research what ESP designing supposed to be.

\section{REFERENCES}

Allwright, R. L. (1984). Why don't learners learn what teachers teach?: The interaction hypothesis. In D. M. Singleton, \& D. Little (Eds.). Language learning in formal and informal contexts. (pp. 3-18). Dublin: Irish Association for Applied Linguistics.

Burkšaitienè Nijolè, (2014), Creative Writing at The University: Students Perceptions and Expectations, Mykolas Romeris University, Institute of Philosophy and Humanities Ateities str. 20 LT-08303 Vilnius, Lithuania

Douglas, D.(2000). Assessing Language for Specific Purposes. Cambridge: Cambridge University Press.

Fahed Al-Serhani, W.(2007). The effect of portfolio assessment on the writing performance of EFL secondary school students in Saudi Arabia. Unpublished MA thesis, Taibah University, Saudi Arabia.

Galina K, Ligija K \& Lilija A (2007) Reflective practice: assessment of assignments in English for Specific Purposes. Mykolas Romeris University \& Vilnius University.Lithuania

Gomer, E.(2001). What Are the Challenges of Assessment Portfolios that Include English Language Learners? 
Ghoorchaei, B., Tavakoli, M., \& Ansari, D. N. (2010). The impact of portfolio assessment on Iranian EFL students' essay writing: A process-oriented approach. GEMA: Online Journal of Language Studies, 10(2), 35-51.

Graddol, D. (2007). English next: The future of English. UK: The British Council

Hamp-Lyons, L., \& Condon, W. (2000). Assessing the portfolio: Principles for practice, theory, and research. Hampton Pr.

Jabbarifar, T (2009) The Importance of Class room assessment and Evaluation in Educational System Yazd University, Proceedings of the 2 International Conference of Teaching and Learning INTI University College, Malaysia

Jones Cherly A (2005). Assessment for Learning. Published by the Learning and Skills Development Agency.www.LSDA.org.uk

Legutke, M \& Thomas. H. (1991) Process and experience in the language classroom. Harlow: Longman

Little, D. (2005). The Common European Framework and the European Language Portfolio: Involving Learners and Their Judgements in the Assessment process, Language Testing 22/2: 321-336.

McCabe, M. (2004). Student Portfolios: Building Fluency. Available from Internet: http://www.ed.gov/ pubs/> (Retrieved March 2010).

McDonough, J. 2002. The Teacher as Language Learner: Worlds of Difference?, ELT Journal 56/4: 404-411.

Nunan, D. (1988). The Learner-centered Curriculum. Cambridge: Cambridge University Press

Nunes, A. (2004). "Portfolios in the EFL classroom: disclosing an informed practice." ELT Journal 58: 327-335

Patak, A. A., Naim, H. A., Said, H., \& Asik, N. (2013). Conceptualizing assessment of final project writing in English as a Foreign Language (EFL): an Indonesian context. In Proceedings of Technology, Education, and Science International Conference (TESIC) 2013: Developing Innovative Technology towards Better Human Life (p. 33). Ibnu Sina Institute for Fundamental Science.

Richards, J. C., \& Rodgers, T. S. (1986). Approaches and methods in language teaching. Cambridge: CUP.

Spratt, M. (1999). "How good are we at knowing what learners like?" System 27: 141155.

Wu Li Fang (2014) Technical College Students' Perceptions of English for Specific Purposes Vocabulary Learning and Teaching Lecturer, Language Education Center Fooyin University, Taiwan

Vygotsky, L. S. (1978). Mind in society. Cambridge, Mass.: MIT Press

Yurdabakan, I., \& Erdogan, T. (2009). The effects of portfolio assessment on reading, listening and writing skills of secondary school prep class students. The Journal of International Social Research, 2(9), 526-538 